In the lateral medullary syndrome frequency of micturition is common and hence it would seem that the efferent fibres from the cerebral hemisphere probably travel in this area of the brain stem; it is of interest that a lesion in this area too will interfere with the sympathetic fibres and produce Horner's syndrome. In the spinal cord the site of the afferent and efferent tracts would now seem to be fairly certain as the result of careful histology of patients who have had bilateral anterolateral cordotomy for intractable pain due to malignant disease. These fibres are present on both sides of the cord about the level of the axis, the motor fibres probably being just anterior to the pyramidal tracts, and the sensory fibres lateral to these in the region of the posterior ends of the lateral spino-thalamic tracts.

Recent work on spinal shock would explain the flaccid bladder which follows immediately on major acute cord damage. The massive disturbance of synapses on the lower motor neurones leads to temporary loss of function of these until function returns once more when the synaptic pattern is re-established weeks later. It would seem likely that the new synaptic pattern is abnormal and hence the spinal bladder is not entirely due to the unmasking of a more primitive physiological reflex but is at least, in part, an abnormal response due to the formation of new synapses.

The most important nerve supply to the bladder is from the sacral cord through the pelvic nerves, which contain both afferent and efferent fibres to the pelvic centre for mircturition. How large a part the sympathetic fibres play in normal micturition is uncertain; so far as one can tell from experimental evidence, the sympathetic supply can be severed without any change in micturition although such damage interferes with normal sexual function.

It is probable too that afferent fibres from the pelvic muscles travelling in the posterior columns can convey some sense of bladder distension due to indirect pressure and hence where a spinal bladder results from bilateral cordotomy the patient may be able to avoid wetting himself as he can take appropriate action when bladder emptying is imminent.

Cauda equina lesions can produce obvious disturbance of bladder function, but the site of the lesion as a rule in this case is fairly obvious on general neurological examination. Recent work from the Mayo Clinic by Love and Emmett suggests that in occasional cases a retropulsed lumbar disc may produce loss of bladder function and chronic urinary retention without any other detectable neurological abnormality. Instances of this type of bladder disturbance in middleaged women are fairly common and hence where there is no evidence of any other pathology to account for the trouble a myelogram should be considered.

\title{
PHARMACOLOGIC STUDIES OF THE NATURE OF THE SYMPATHETIC NERVES OF THE URINARY BLADDER
}

By Saul Boyarsky, M.D., Peregrina Labay, M.D., Robert Gregg, M.D., and Benton Levie M.D.

From Duke University Medical Center, Durham, North Carolina, and the Veterans Administration Hospital, Durham, N.C., Division of Urology, Dept. of Surgery

THE purpose of this presentation is to reconsider the role of the sympathetic nerves of the urinary bladder in the light of the apparent relaxation of bladder tone by Isoproterenol, the beta-adrenergic stimulator. 
Innervation. Although there is little doubt that the urinary bladder receives innervation from the lumbar sympathetic cord, the second through the fifth segments along the rami communicantes through the hypogastric nerves, there is some question as to the proportion of bladder muscle cells receiving this innervation. Although the pattern of innervation varies from species to species, it has been shown that sympathetic innervation of the bladder supplies both the dome of the bladder and the base. The parasympathetic cholinergic nerves from the sacral cord (Learmonth, I93I; Ingersoll and Jones, I958; Kuru, I965), furnish a richer innervation to the bladder musculature and a more thorough innervation to each muscle cell through the pelvic nerves. This latter route is unquestionably the motor supply of the muscles of micturition (Kuntz, I953; Kuru, I965).

The only drugs accepted for effective bladder response to date are those acting upon the cholinergic system.

The role of the sympathetic nerves of the bladder has been variously interpreted, depending upon the bent and interests of the writer or the particular viewpoint cast by his methodology. Thus, one author informs us that the sympathetic nerves of the bladder have no function, other than to close the internal sphincter during ejaculation so as to prevent the retrograde expulsion of semen into the bladder. Other workers describe experiments in which hypogastric nerve stimulation in several species produced a weak contraction, intermittent or poorly sustained contraction, or a contraction followed by a relaxation. Others describe a localised or a unilateral contraction (Learmonth, I93 I; Ingersoll and Jones, I958; Kuru, 1965). When all else fails, sympathetic nerves can be grouped with the blood vessels and a vasomotor function attributed to them.

Finally, the 'practical' investigator author brushes aside this confusion and writes 'the time honoured theory of dual antagonistic innervation of the bladder is no longer tenable. This theory implied that stimulation of the sympathetic fibres contracted the vesical neck and relaxed the detrusor muscle, whereas stimulation of the parasympathetic fibres relaxed the vesical neck and initiated contraction of the detrusor. It is generally accepted that the sympathetic system has no influence on the initiation, maintenance or inhibition of urination in human beings. This concept is supported by experimental studies in the normal subject and in the paraplegic patient which have demonstrated that neither stimulation nor inhibition of the thoracolumbar or sympathetic portion of the autonomic nervous system had any effect on urination' (Greene and Emmett, I963).

We do not propose to unravel all this confusion at once. Rather we propose to introduce another element into the problem, the role of beta-adrenergic receptors, whose recognition may resolve some of the difficulties in interpretation of previous experiments. A review of the literature suggests to us that only a few investigators have considered the possibility that the sympathetic system could relax the bladder detrusor.

Neuropharmacology. The neurohumoral theory of transmission in the sympathetic nervous system includes two types of adrenergic receptors. A pattern of dual receptors has been described for many organs including the vas deferens, ileum and ureter (Innes and Nickerson, I965; Boyarsky and Labay, unpublished data).

The sympathetic nervous system actually causes relaxation of certain smooth muscle structures, as typified by action of epinephrine on bronchial musculature 
causing dilation in treatment of asthma. These sympathetic inhibitory actions are classified as beta-adrenergic and include relaxation of the smooth muscle, in arteries, uterus, ureter and other organs. The vasoconstriction, the smooth muscle contraction and similar phenomenon are termed the alpha-adrenergic actions. (Paradoxically, the same conditions and agents which evoke the smooth muscle relaxation for beta-adrenergic effects increase the force and rate of myocardial contractions, so that the myocardial musculature is thought to possess betaadrenergic receptors.) The palpitations caused by Isuprel are well known in clinical experience.

Pharmacologists have studied the various sympathomimetic drugs and adrenergic blockers. Their predilection for alpha-receptors and beta-receptors has been quantitated (Innes and Nickerson, I965). Most sympathomimetic drugs stimulate both types of receptors but several stand out on each end of the spectrum. Phenylephrine or neosynephrine has an almost pure alpha-stimulating action with very little effect on beta-receptors. Hence, it would affect the heart only slightly and would cause vasoconstriction and spasm of sympathetically innervated smooth muscle. On the other side of the spectrum is isoproterenol which activates the beta-adrenergic receptors, including those in the heart, but has little effect on the alpha-receptors. The molecular biology of the two types of receptors is under active investigation (Bellau, I967).

The propensity of certain drugs for alpha-receptors and others for betareceptors is well known. In the present work, the predilection of beta-receptors to stimulation by isoproterenol is used as a tool to demonstrate these receptors.

General Methods. Our present concepts of bladder physiology are based on the studies of many species, dog, cat, rabbit, guinea-pig, rat and humans. Human patients as well as volunteers have been studied. These species have been studied in the conscious, the anesthetised, and the diseased states after destruction of various portions of the central and peripheral nervous system (Girado and Campbell, I959; Ursillo, I96I; Gyermek, I96I; Bors, I963; Sigg and Sigg, 1964; Hukovic et al., I965; Cheshire and Thorpe, 1965; Carpenter and Rand, 1965; Tanagho et al., I966; Wimber et al., I966; Tanagho and Smith, I966; El-Badawi and Schenk, I966; Boyarsky et al., I967; Bradley, I967; Perlmutter, I967). The excised bladder has been studied, with the pelvic nerve or with the hypogastric nerves intact. It has also been studied in situ with the urethra, contiguous or transected. In vitro, strips of bladder muscle with and without the pelvic nerve have been studied both mechanically and electrophysiologically. Manometric, visual, histologic and biochemical observations have been made upon these various preparations and subjects. Urodynamic or manometric methods or the 'cystometrogram', have recently been extended to include the emptying phase, by the measurement of urethral flows, bladder capacity, the monitoring of extravesical pressures from the rectum, peritoneal cavity and urethra, and the physiologic monitoring of the systemic blood pressure and bladder sensation.

A modification of the cystometrogram is the isometric, rather than the isotonic cystometrogram, in which the development of tension in the wall of the muscle at a constant volume is measured during contraction rather than during filling and emptying.

Since voiding involves more than just the bladder itself, the monitoring of the activity of the accessory muscles of micturition by electromyography or other 
methods has proven to be an invaluable supplement to the understanding of micturition itself.

Visual observation of the bladder during its cycle of function can be carried out surgically. It has also been recorded cinefluorographically and by other radiologic techniques.

Biochemical assays of catecholamine in the bladder wall, acetylcholine contents of bladder urine and venous effluent have been reported. Histologic and histochemical studies of the bladder wall for cholinergic and adrenergic fibres have been very informative. Lastly, the response of the bladder to pharmacologic agents administered by the intravenous, intra-arterial, local or other routes in vivo and in vitro have been used to study bladder physiology.

It is our impression that observations made on patients are scientifically more fragmentary than those made on animals for at least three reasons: (I) The necessary restriction of dosage, (2) the cruder scientific criteria used, because patient handling must give way to patient safety, and (3) reasoning from therapeutic results rather than physiologic mechanisms. In general, observations from humans have been used to confirm or refute a theoretical schema developed from the research laboratory. But this is true for any branch of medicine.

\section{METHODS}

Technique. Our methods were the simplest we could devise. No method of studying the bladder is free of theoretical or technical criticism.

Dogs under sodium pentobarbital anesthesia were catheterised with a \# I6 French retention catheter and the bladder filled rapidly at a rate of 10 to $20 \mathrm{cc}$. per minute, as the intravesical pressure was monitored continuously through a \#6 French ureteral catheter passed parallel to the first catheter through the urethra. This fluid-filled catheter was connected to a pressure transducer and electronic recorder. The bladder was allowed to fill until voiding around the catheter occurred. Under anesthesia voiding was incomplete. The intravesical pressure during filling, during micturition and after micturition was traced continuously. Then the amount voided and the residual urine were determined. The total bladder capacity was calculated.

In some experiments, blood pressure was recorded from an arterial catheter on another channel of the same recorder. Drugs were administered through an intravenous needle kept patent by isotonic saline or 5 per cent. glucose and water running at a very slow rate. Other injections were made through an intra-arterial femoral catheter passed through a cut-down into the aorta to a point just above the bifurcation.

Each experiment contained its own controls. Two to three cystometrograms were performed in each experiment before the test drug was administered. Then, two to three cystometrograms were repeated during the influence of the drug; in some experiments further cystometrograms were performed after recovery. As each animal provided its own controls the only variable was the drug injected.

The cystometrogram is conventionally described in terms of a filling limb and a voiding curve (Kuru, 1965; Zinner and Ritter, 1967).

Although the filling limb depends mainly upon the properties of the vesical smooth muscle it is also influenced by the intrinsic nerves, receptors and ganglia of the bladder and to some extent by the activity of the central nervous system. 
Similarly the contraction phase of the cystometrogram represents the co-ordinated contraction of the detrusor muscle whose level of response depends upon the micturition centres, and this in turn is influenced by the properties of the bladder wall and the pressures developed.

\section{RESULTS}

Figure I shows the typical tracing of a cystometrogram before and after isoproterenol administration. The dotted line (control) shows the rather flat filling limb in one dog, and the rather sharp steep contraction limb here rising to a maximum of $60 \mathrm{~mm}$. of mercury. The solid line (experimental) shows that the filling pressure was a little less, some $3 \mathrm{~mm}$. of mercury less, and that the filling of the bladder much greater so that the total bladder capacity changed from I6o cc. to $300 \mathrm{cc}$. The maximum voiding pressure was almost half that of the control. Not shown on the graph are the findings that the bladder emptying was less efficient, the residual urine was larger. These data represent the average of three determinations for each curve.

Control experiments in which the same cystometrogram was repeated under light and heavy anaesthesia, and for as many as seven consecutive determinations showed that the effect of repetition was to decrease the bladder capacity (Table I).

TABLE I

Effect of Sodium Pentobarbital Anaesthesia on Bladder Parameters ${ }^{1}$

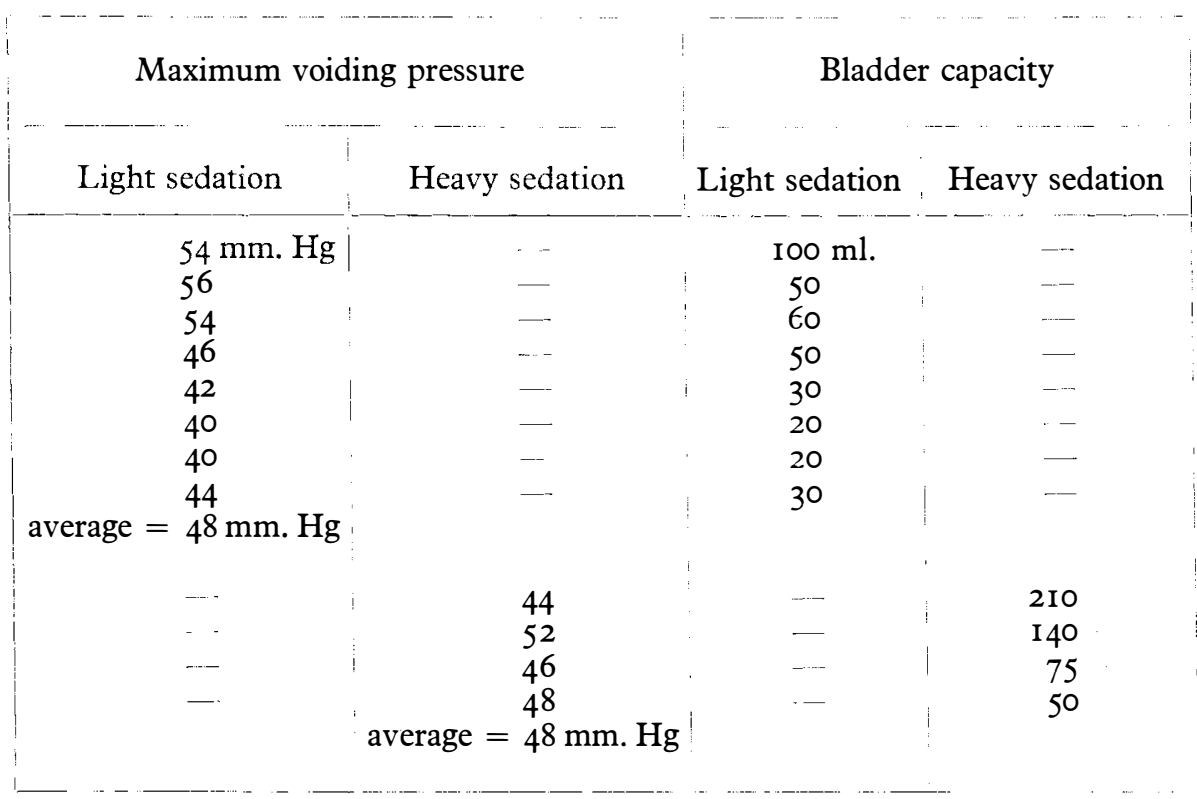

1 The dog was only very lightly sedated. A series of seven voidings were taken, after which the dog was given 0.5 cc. more of sodium pentobarbital, and a series of four more voidings were taken. Note that the voiding pressure was not influenced by the anaesthesia. The capacity measurements are too variable to make a conclusion. 


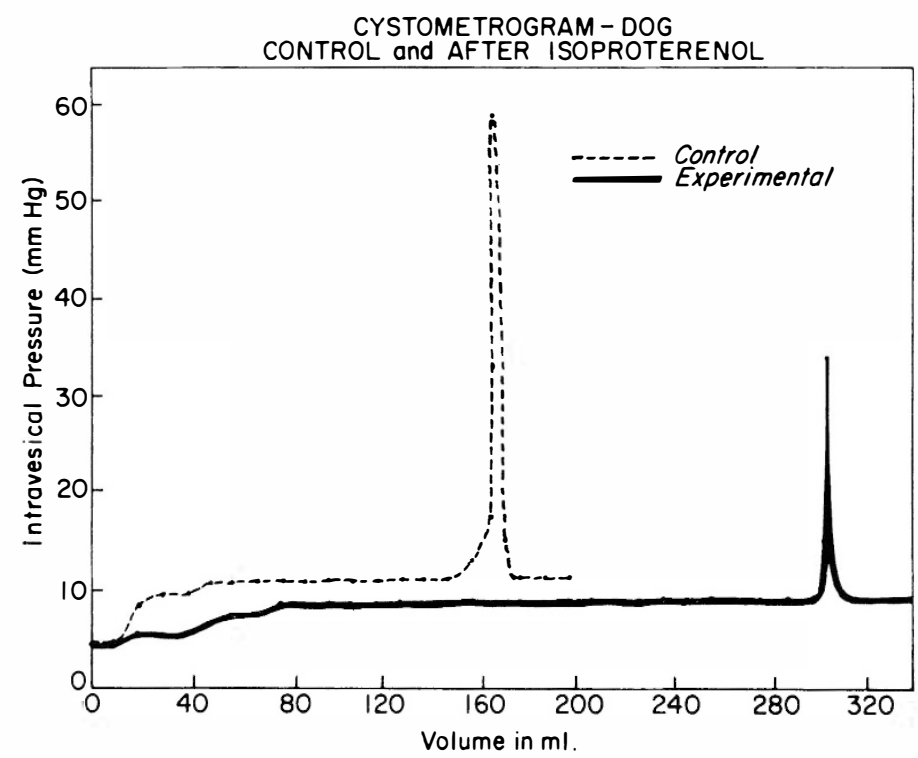

FIG. I

Cystometrogram-Dog. Control and after isoproterenol.

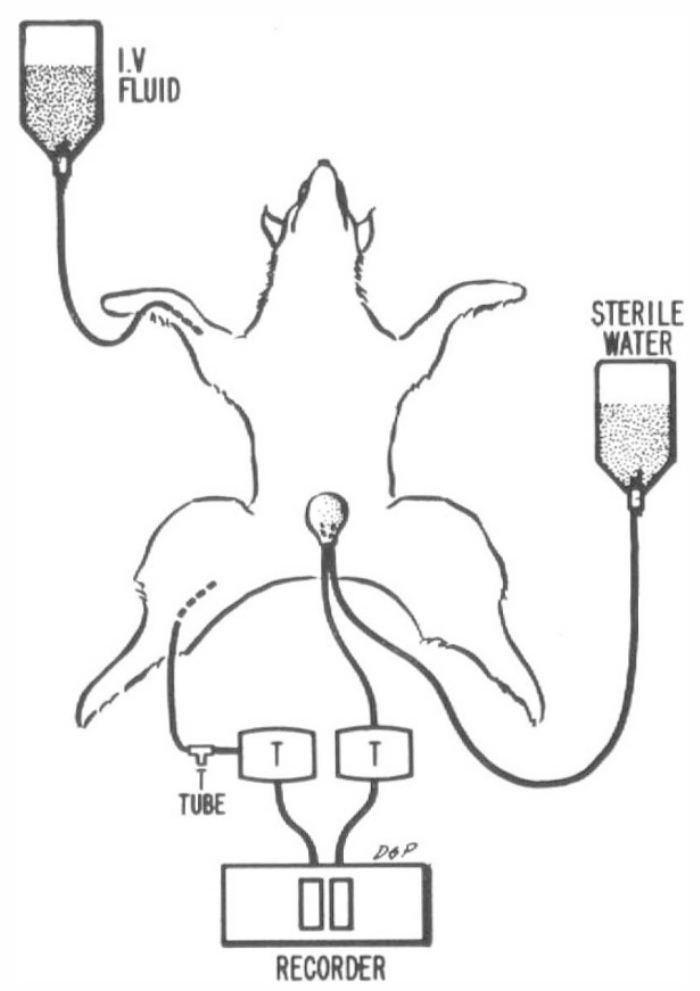

FIG. 2

Diagram of technique of cystometrogram showing bladder catheter, transducers and twin-channel recorder. Blood pressure is monitored from femoral artery catheter. 
Dose. The initial experiments were performed with a saturation dose of $3 \mathrm{mg} . / \mathrm{kg}$. I.V. A single injection seemed to maintain sufficient isoproterenol for a one to two hour effect.

After such injection the maximal voiding pressure fell an average of 37 per cent. in seven experiments. Bladder capacity rose an average of Ioo per cent. while the residual urine increased a variable amount and over a much wider range. Almost all the animals showed these changes in almost all the parameters (Tables II, III, IV).

TABLE II

Effect of Maximal Voiding Pressure Seven Experiments-Dogs (Maximal voiding pressure minus pre-voiding pressure)

\begin{tabular}{|c|c|c|c|}
\hline \multirow{2}{*}{ Dog No. } & \multicolumn{3}{|c|}{$\begin{array}{l}\text { Maximal voiding pressure } \\
\text { (in } \mathrm{mm} . \mathrm{Hg} \text { ) }\end{array}$} \\
\hline & Control & $\begin{array}{l}\text { Isoproterenol } \\
3 \mathrm{mg} . / \mathrm{kg} \mathrm{I.V.}\end{array}$ & $\begin{array}{l}\text { Percentage } \\
\text { decrease }\end{array}$ \\
\hline 66-2I2 (Ist study) & $48(4)$ & $30(4)$ & 38 \\
\hline 66-206 (Ist study) & $44(4)$ & $2 \mathrm{I}(3)$ & 52 \\
\hline 66-200 (Ist study) & $55(5)$ & $20(\mathrm{I})$ & 64 \\
\hline 66-2 I 2 (2nd study) & $45(4)$ & $26(2)$ & 42 \\
\hline $66-I 99$ & $4 \mathrm{I}(2)$ & $27(2)$ & 34 \\
\hline 66-200 (2nd study) & 28 (2) & 24 (I) & I 4 \\
\hline 66-206 (2nd study) & I6 (I) & I8 (2) & - \\
\hline
\end{tabular}

Note. Values given are averages. Number of values used in computing average is given in parentheses.

TABlE III

Effect on Bladder Capacity-Dogs

\begin{tabular}{|c|c|c|c|}
\hline \multirow{3}{*}{ Dog No. } & \multicolumn{3}{|c|}{ Bladder capacity } \\
\hline & & $\ldots$ & -.. \\
\hline & Control & $\begin{array}{l}\text { Isoproterenol } \\
3 \mathrm{mg} . / \mathrm{kg} \text {. I.V. }\end{array}$ & $\begin{array}{l}\text { Percentage } \\
\text { increase }\end{array}$ \\
\hline $66-2$ I2 (Ist study) & I I9 cc. (4) & $249(4)$ & I IO \\
\hline 66-206 (Ist study) & I39 cc. (4) & $337(3)$ & 140 \\
\hline 66-200 (Ist study) & I IO cc. (4) & I40 (I) & 30 \\
\hline 66-212 (2nd study) & 67 cc. (3) & $265(2)$ & 290 \\
\hline $66-199$ & $60 \mathrm{cc}$. (3) & $328(2)$ & 280 \\
\hline $66-200$ (2nd study) & 345 cc. (2) & $300(I)$ & I4 decrease \\
\hline $66-206$ (2nd study) & 580 cc. (I) & $400(2)$ & 30 decrease \\
\hline
\end{tabular}

Note. Values given are averages. Number of values used in computing average is given in parentheses. 
A SYMPOSIUM ON THE NEUROGENIC BLADDER

TABLE IV-Effect on Residual Urine and Degree of Emptying-Dogs

\begin{tabular}{|c|c|c|c|c|}
\hline \multirow[b]{2}{*}{ Dog No. } & \multicolumn{2}{|c|}{ Residual urine } & \multicolumn{2}{|c|}{$\begin{array}{c}\text { Degree of emptying } \\
\text { (amount voided/bladder capacity) }\end{array}$} \\
\hline & Control & $\begin{array}{l}\text { Isoproterenol } \\
3 \mathrm{mg} . / \mathrm{kg} . \mathrm{I} . \mathrm{V} \text {. }\end{array}$ & $\begin{array}{c}\text { Control } \\
(\%)\end{array}$ & $\begin{array}{l}\text { Isoproterenol } \\
3 \mathrm{mg} . / \mathrm{kg} \mathrm{I} . \mathrm{V} . \\
(\%)\end{array}$ \\
\hline 2I2 (Ist study) & $\begin{array}{l}15 \\
25 \\
-\end{array}$ & $\frac{-}{115}$ & $\begin{array}{l}20 / 35=57 \\
25 / 50=50 \\
-\end{array}$ & $\begin{array}{l}\bar{\tau} \\
80 / 235\end{array}=34$ \\
\hline 206 (Ist study) & 65 & 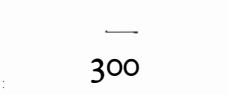 & $70 / 135=52$ & $\mathrm{IIO} / 4 \mathrm{IO}=27$ \\
\hline 200 (Ist study) & 80 & 85 & $45 / 125=36$ & $55 / 140=39$ \\
\hline 2 I 2 (2nd study) & $\begin{array}{l}25 \\
10 \\
15 \\
- \\
-\end{array}$ & $\begin{array}{c}- \\
- \\
- \\
140 \\
160\end{array}$ & $\begin{array}{c}25 / 50=50 \\
40 / 50=80 \\
60 / 75=80 \\
-\end{array}$ & $\begin{array}{c}\bar{\cdots} \\
\overline{-} \\
125 / 265=47 \\
90 / 250=36\end{array}$ \\
\hline 200 (2nd study) & $\begin{array}{l}220 \\
170 \\
--\end{array}$ & $\begin{array}{c}-\cdot \\
-- \\
230\end{array}$ & $\begin{array}{l}\mathrm{I} 60 / 380=42 \\
\mathrm{I} 40 / 3 \mathrm{IO}=45\end{array}$ & $70 / 230=23$ \\
\hline 206 (2nd study) & $\underline{140}$ & 250 & $425 / 565=75$ & $80 / 330=24$ \\
\hline I99 & $\begin{array}{l}0 \\
\cdots \\
\cdots \\
\cdots\end{array}$ & $\begin{array}{l}70 \\
80\end{array}$ & $\begin{array}{c}40 / 40=100 \\
-\end{array}$ & $\begin{array}{c}\overline{-} \\
140 / 310=67 \\
160 / 240=67\end{array}$ \\
\hline
\end{tabular}

TABle V-Effect on Maximum Voiding Pressure-Cats

\begin{tabular}{|c|c|c|c|}
\hline \multirow{2}{*}{ Cat No. } & \multicolumn{2}{|c|}{ Maximum voiding pressure } & \multirow[b]{2}{*}{$\begin{array}{l}\text { Percentage } \\
\text { Reduction }\end{array}$} \\
\hline & Control & $\begin{array}{l}\text { With isoproterenol } \\
3 \mathrm{mg} . / \mathrm{kg} . \mathrm{I} . \mathrm{V} .\end{array}$ & \\
\hline$\# \mathrm{I}$ (Ist study) & $26(5)$ & $8(2)$ & 70 \\
\hline$\# \mathbf{I}$ (2nd study) & $39(3)$ & I7 (3) & 56 \\
\hline$\# 2$ & IO (2) & $4(2)$ & 60 \\
\hline
\end{tabular}

Note. Values given are averages. Number of values used in computing averages is given in parentheses. 
Three experiments were performed in two cats with very similar findings (Tables V, VI, VII). This satisfied us that the isoproterenol effect was not speciesspecific in the dog. We determined in subsequent experiments that I mg./kg. I.V. could elicit the same effect (at a similar magnitude) and $0.5 \mathrm{mg} . / \mathrm{kg}$. I.V. (three experiments in two dogs) had a similar effect.

TABLE VI-Effect on Bladder Capacity-Cats

\begin{tabular}{|c|cc|c|}
\hline Cat No. & Bladder capacity & \\
& & & \\
& Control & $\begin{array}{c}\text { With isoproterenol } \\
\text { 3 mg./kg. I.V. }\end{array}$ & $\begin{array}{c}\text { Percentage } \\
\text { increase }\end{array}$ \\
\hline \#I (Ist study) & $24(5)$ & $30(2)$ & 25 \\
$\#$ I (2nd study) & $24(3)$ & $29(2)$ & 2 I \\
$\# 2$ & 5I (2) & $74(2)$ & 45 \\
\hline
\end{tabular}

Note. Values given are averages. Number of values used in computing average is given in parentheses.

TABLE VII-Effect on Degree of Emptying-Cats

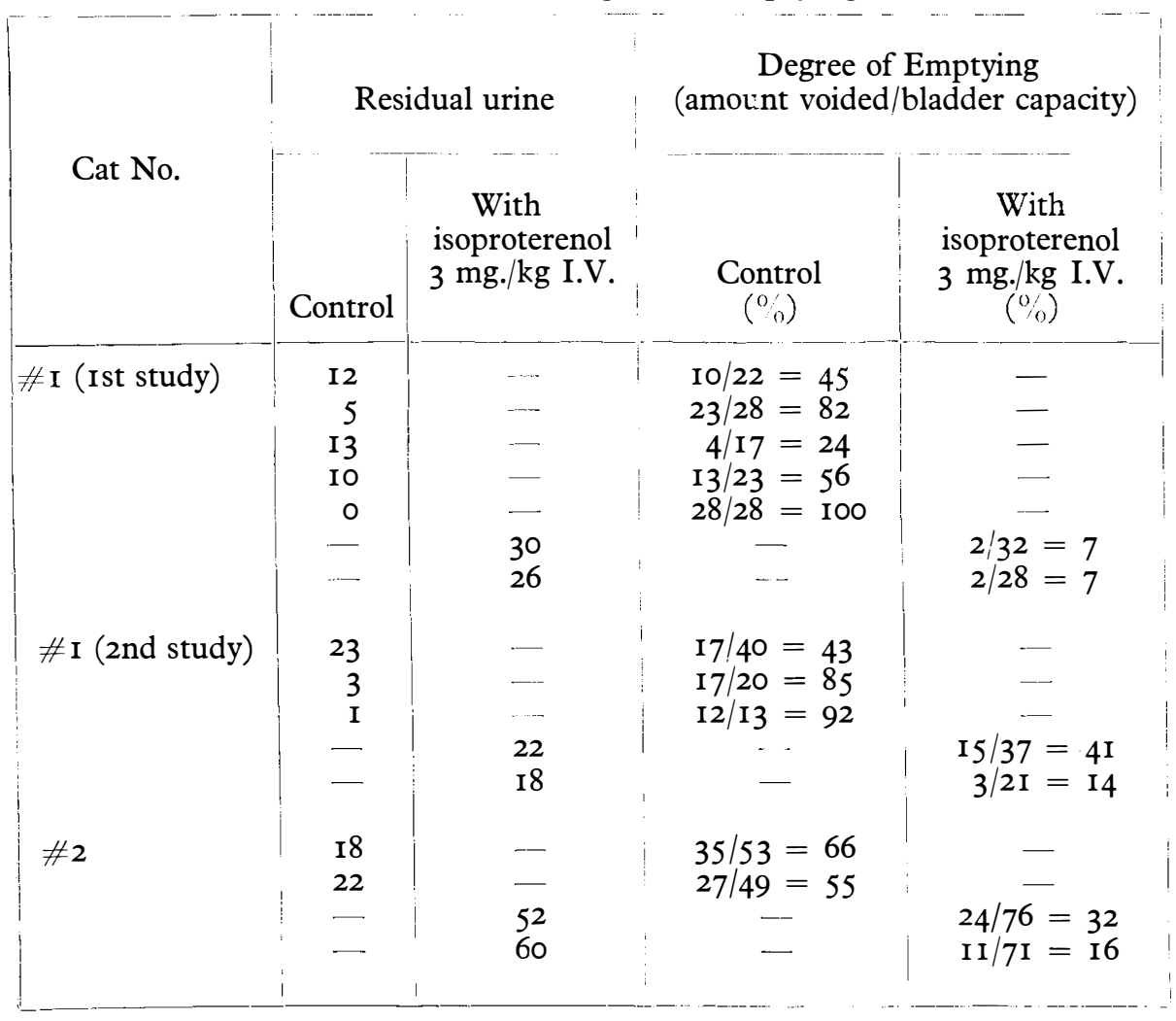


Blood pressure fell from levels of 200/135 to levels of $140 / 60$. There was no correlation in time or in degree between the hypotensive and vesical effect of isoproterenol. Indeed, later on, use of phentolamine (below) produced greater blood pressure changes while intravesical pressure rose rather than fell.

Route of Administration. Using the arterial route of administration, in I8 experiments we established very quickly that the dosage could be reduced from $3 \mathrm{mg}$. $/ \mathrm{kg}$. to $0.5 \mathrm{mg}$. $/ \mathrm{kg}$. I.V. and from $0.5 \mathrm{mg}$. $/ \mathrm{kg}$. I.A. to $4 \mu \mathrm{g}$. $/ \mathrm{kg}$. $/ \mathrm{min}$. I.A. constant infusion (Tables VIII, IX).

\section{TABLE VIII}

Effect of Isoproterenol $0.5 \mathrm{mg} . / \mathrm{kg}$. Intra-aortically upon Cystometrogram of Dog

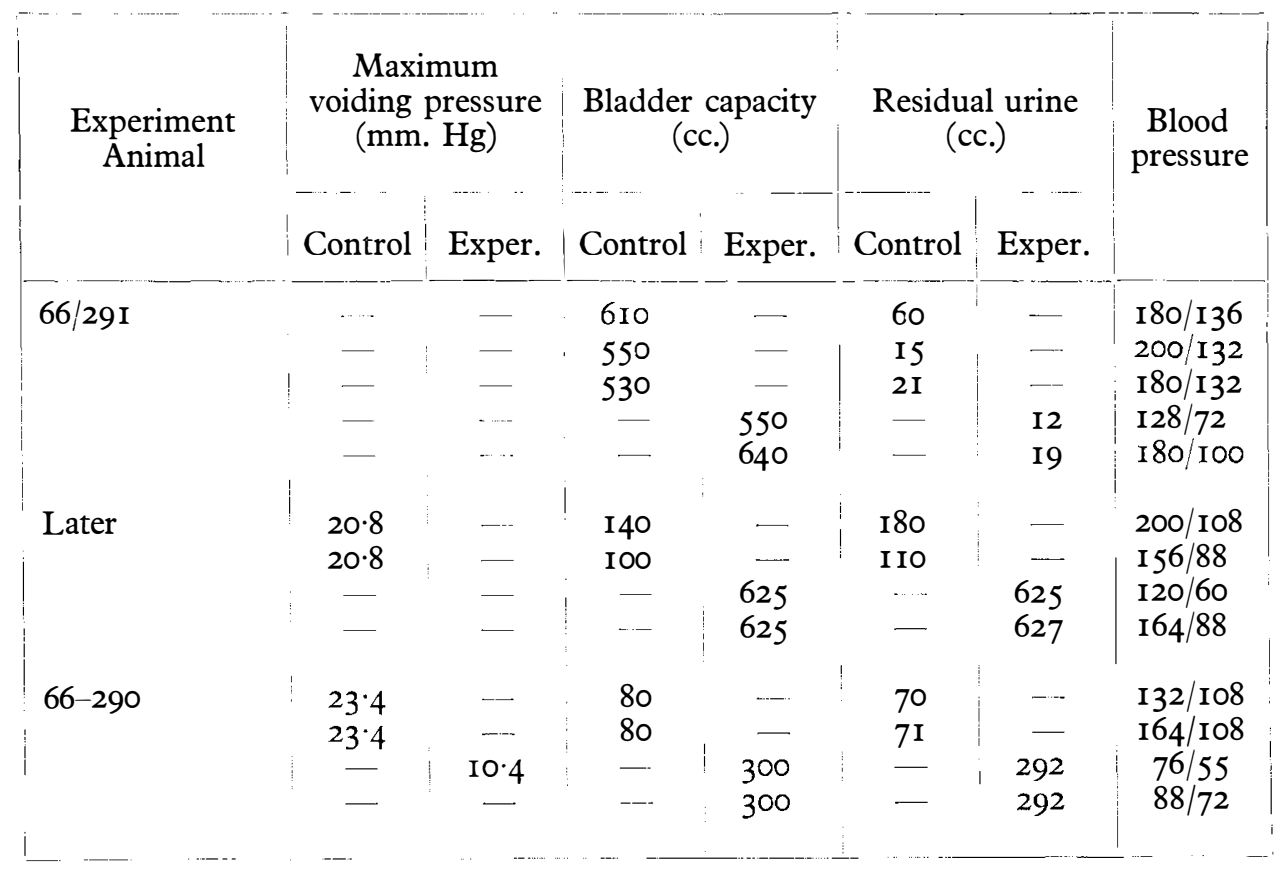

Direct injection of the hypogastric arteries required dissection and dislocation of the bladder introducing too many uncontrollable factors; so, a \# I6 French ureteral catheter was passed retrograde through a femoral artery cutdown to a point just proximal to the bifurcation of the aorta for intra-aortic injection into the hypogastric and vesical arteries.

However, when the dose was reduced to $2 \mu \mathrm{g}$. $/ \mathrm{kg}$. $/ \mathrm{min}$. constant infusion, I.A., the threshold was reached, as threshold was defined by the three criteria used at the start of these experiments. This lesser dose tended to lower the maximum voiding pressure and raised the residual urine, but did not alter the capacity. Undoubtedly, we could have recorded a lower threshold dose had we been willing to measure just the maximum voiding pressure, but until further experience and 


\section{TABLE IX}

Effect of Isoproterenol $4 \mu \mathrm{g} . / \mathrm{kg}$. $/ \mathrm{min}$. I.A. on Cystometrogram of Dog (along with atropine $0.5 \mathrm{mg} . / \mathrm{kg}$. I.V. and phentolamine $0.3 \mathrm{mg}$. $/ \mathrm{kg}$. I.V.)

\begin{tabular}{|c|c|c|c|c|c|c|c|c|}
\hline \multirow{2}{*}{$\begin{array}{c}\text { Experiment } \\
\text { Animal }\end{array}$} & \multicolumn{2}{|c|}{$\begin{array}{l}\text { Maximum } \\
\text { voiding pressure } \\
(\mathrm{mm} . \mathrm{Hg})\end{array}$} & \multicolumn{2}{|c|}{$\begin{array}{l}\text { Bladder capacity } \\
\text { (cc.) }\end{array}$} & \multicolumn{3}{|c|}{$\begin{array}{l}\text { Residual urine } \\
\text { (cc.) }\end{array}$} & \multirow{2}{*}{$\begin{array}{c}\text { Blood } \\
\text { pressure } \\
(\mathrm{mm} . \mathrm{Hg})\end{array}$} \\
\hline & Control & Exper. & Control & Exper. & Control & & Exper. & \\
\hline \multirow[t]{8}{*}{ 66-219 } & - & --- & 130 & $\ldots . .$. & 65 & & -. & -- \\
\hline & 34 & - & 100 & - & 24 & & -.. & - \\
\hline & 40 & - & 90 & - & 30 & & $-\cdots$ & -- \\
\hline & 38 & -- & I 20 & - & I9 & & -. & -- \\
\hline & - & 22 & -- & 260 & - & & 205 & - \\
\hline & $\cdots$ & I8 & $\cdots$ & 270 & - & & 265 & - \\
\hline & Recovery & I4 & - & 280 & 一 & & 280 & 一 \\
\hline & 32 & - & 130 & $-\cdots$ & 86 & & - & -- \\
\hline \multirow[t]{7}{*}{$67-42$} & I7 & -- & 80 & - & 73 & & $\cdot-$ & I 80/I24 \\
\hline & I6 & -- & 40 & - & 50 & ; & - & - \\
\hline & 25 & -- & 30 & - & 74 & & $\ldots$ & $-\cdots$ \\
\hline & 25 & --- & 60 & - & 67 & 1 & -- & $-\cdots$ \\
\hline & 一 & 28 & $\ldots$ & 120 & 一 & & IIO & $70 / 36$ \\
\hline & 一 & 20 & $\cdots$ & 120 & - & & 97 & $88 / 42$ \\
\hline & - & I 8 & $-\cdots$ & I 40 & - & & 98 & $88 / 42$ \\
\hline \multirow[t]{6}{*}{$67-4 \mathrm{I}$} & 20 & - & 400 & - & 285 & & $\ldots .$. & I $60 /$ I IO \\
\hline & 34 & - & 250 & $\ldots$ & 128 & & - & - \\
\hline & 34 & -- & $I 60$ & - & I06 & & $\cdots$ & - \\
\hline & - & I6 & - & 560 & - & I & 550 & $100 / 35$ \\
\hline & - & I8 & $-\cdot$ & 570 & $\cdots$ & & 520 & - \\
\hline & I8 & - & I 40 & -- & I૯O & & - & -- \\
\hline \multirow[t]{8}{*}{$67-5 \mathrm{I}$} & 26 & $-\cdots$ & 290 & - - & 230 & & - & --- \\
\hline & -- & 6 & - & 324 & - & & 239 & - \\
\hline & $-\cdots$ & 9 & $\cdots$ & 284 & - & & 265 & $\cdot-$ \\
\hline & 一 & 6 & 一 & 236 & -- & 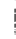 & 234 & -- \\
\hline & I3 & -- & 255 & 一 & 215 & & - & $\cdots$ \\
\hline & I4 & -- & 190 & - & 170 & & - & - \\
\hline & I3 & - & I 20 & - & I06 & 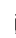 & - & - \\
\hline & I 5 & - & I IO & - & 97 & & $\cdots-$ & $\cdots$ \\
\hline
\end{tabular}

knowledge about bladder function are gained we are unwilling to decide which parameter is to be sacrificed and which parameter is to be retained as the index of bladder function for mathematic treatment. At this point it does appear that none of these criteria is ideal, unless pressure is assumed to be a direct measure of mural tension (Table $\mathrm{X})$. 
TABLE X

Effect of Isoproterenol $2 \mu \mathrm{g} . / \mathrm{kg} . / \mathrm{min}$. Intra-aortically on Cystometrogram (with atropine $0.5 \mathrm{mg} . / \mathrm{kg}$. I.V. and phentolamine $0.3 \mathrm{mg} . / \mathrm{kg}$. I.V.

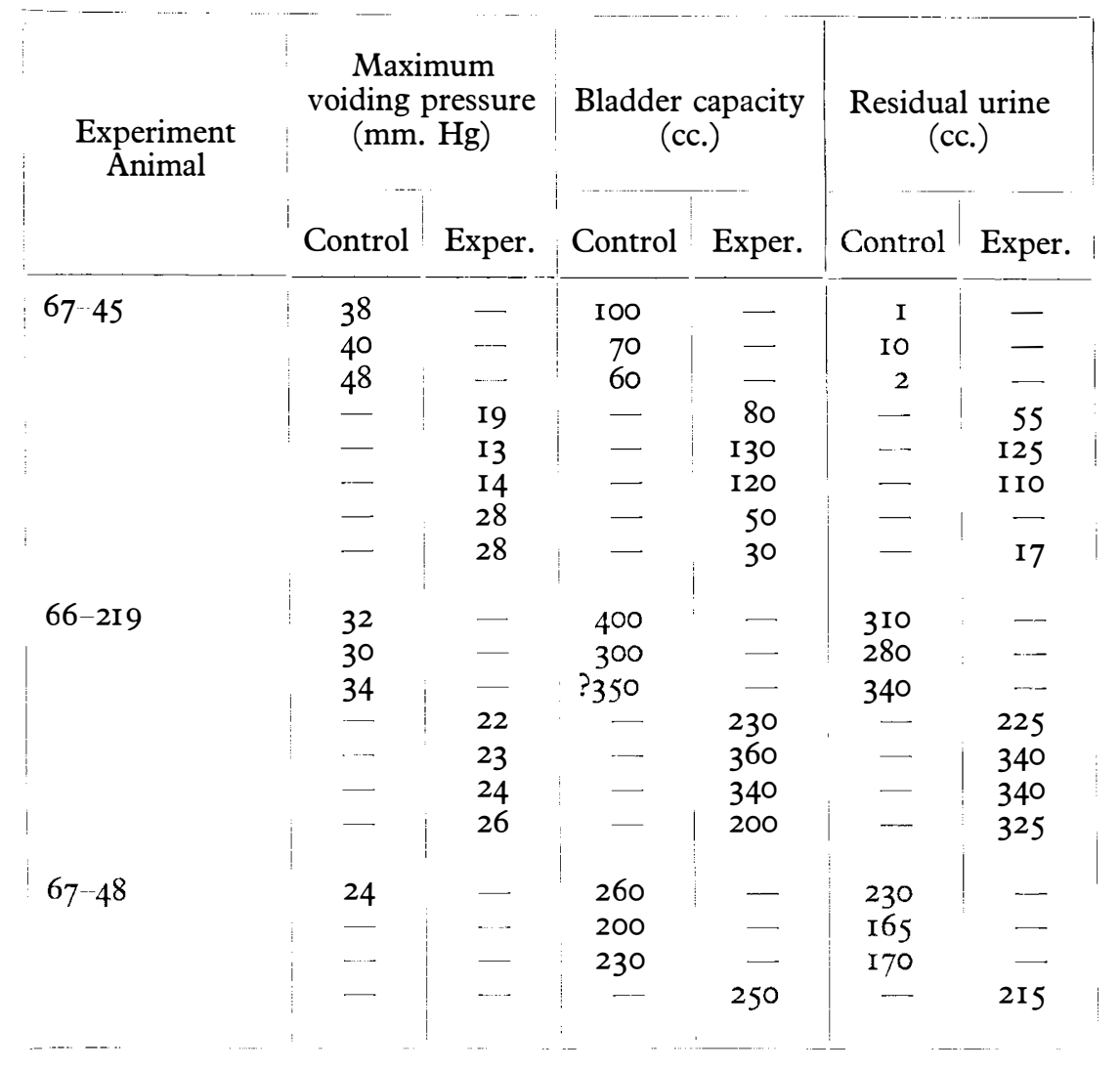

Other Critical Experiments. Was this effect secondarily vesical, but elicited in the central nervous system, the adrenal gland or the parasympathetic nervous system?

In 20 experiments, atropine, $0.5 \mathrm{mg}$. $/ \mathrm{kg}$. was administered intravenously before the procedure, and once midway during the procedure with no change; neither enhancement nor lessening of the isoproterenol effect resulted.

In 19 dogs, phentolamine $0.3 \mathrm{mg}$. $/ \mathrm{kg}$. was administered intravenously, both with the isoproterenol in a few experiments, then with the atropine prior to the control determinations in most of the experiments. Again no change in the isoproterenol effect was noted from this alpha-adrenergic blockade by phentolamine. It was interesting that the phentolamine lowered the blood pressure more effectively than the isoproterenol.

Preliminary experiments with beta-adrenergic blocking agents have shown that the effect of isoproterenol can be negated by the use of these drugs. These data will be published later. 
Reversibility. Unless isoproterenol was administered repeatedly, its effect was not maintained. Such recovery was best demonstrated by using intra-aortic continuous infusions at low dose levels. The effect of isoproterenol in a continuous infusion of $4 \mu \mathrm{g} . / \mathrm{kg} . / \mathrm{min}$. I.A. on the cystometrogram was quite like that depicted in Figure $\mathrm{I}$ for a large single injection.

The filling volume was extremely large, $570 \mathrm{cc}$. and the residual urine was some few cc. less than that volume.

In 43 minutes after cessation of the infusion one dog showed a voiding pressure approaching $30 \mathrm{~mm}$. of mercury and the bladder capacity was I30 cc. in this animal.

During isoproterenol infusion the cystometrogram curve had been as flat as the experimental graph. Hence, the effect of isoproterenol on the bladder is not permanent nor irreversible.

Intravesical Pressure. Could we demonstrate a direct lowering of intraluminal pressure, and presumably the mural tension? Intravesical pressure fell during isoproterenol infusion before micturition as well as during micturition. A similar phenomenon was produced in several experiments by making an injection at a specific point in time to observe the instantaneous response to the injection. A fall of $3 \mathrm{~mm}$. $\mathrm{Hg}$. from 9 to $6 \mathrm{~mm}$. in one experiment, and a fall of $13 \mathrm{~mm}$. $\mathrm{Hg}$ from 9 to $6 \mathrm{~mm}$. in one experiment, and a fall of $\mathrm{I} 3 \mathrm{~mm}$. $\mathrm{Hg}$ from $22 \mathrm{~mm}$. to $9 \mathrm{~mm}$. in another was produced by $40 \mu \mathrm{g} . / \mathrm{kg}$. I.V.

Dr. Joseph Malin has made preliminary observations in vitro in our laboratory to demonstrate relaxation of strips of bladder wall to bath concentration of $0.0 \mathrm{I}$ $\mu \mathrm{g} . / \mathrm{ml}$. of isoproterenol.

Effects of 'Pharmacologic Opposite'. It remained next to try phenylephrine, the alpha-adrenergic activator drug, to see if its effects would be opposite to those of isoproterenol.

\section{TABLE XI}

Effect of Phenylephrine, $2 \mu \mathrm{g} . / \mathrm{kg} . / \mathrm{min}$. I.A. on Cystometrogram-One Dog

\begin{tabular}{|c|c|c|c|c|c|}
\hline \multicolumn{2}{|c|}{$\begin{array}{l}\text { Maximum } \\
\text { voiding pressure } \\
\text { (mm. } \mathrm{Hg} \text { ) }\end{array}$} & \multicolumn{2}{|c|}{$\begin{array}{l}\text { Bladder capacity } \\
\text { (cc.) }\end{array}$} & \multicolumn{2}{|c|}{$\begin{array}{l}\text { Residual urine } \\
\text { (cc.) }\end{array}$} \\
\hline Control & Exper. & Control & Exper. & Control & Exper. \\
\hline I 8 & $3^{2-40}$ & 370 & I 40 & 265 & 80 \\
\hline I 2 & 30 & 260 & 160 & 105 & 30 \\
\hline 24 & 30 & 227 & 180 & 210 & 50 \\
\hline 24 & - & 230 & - & 75 & $\ldots . .$. \\
\hline
\end{tabular}

First the effect on the intravesical pressure of a single injection of $\mathrm{IO} \mu \mathrm{g}$. $/ \mathrm{kg}$. I.A. was noted to be opposite to that of isoproterenol. In one experiment the pressure rose $2 \mathrm{~mm}$. $\mathrm{Hg}$, from 9 to I I $\mathrm{mm}$. $\mathrm{Hg}$, and after a second dose it rose $7 \mathrm{~mm}$. $\mathrm{Hg}$, from 8 to $15 \mathrm{~mm}$. $\mathrm{Hg}$, during the filling limb of the cystometrogram. 
In a second dog the intra-aortic infusion of $2 \mu \mathrm{g} . / \mathrm{kg} . / \mathrm{mm}$. produced changes from 4 to $6 \mathrm{~mm}$. Hg. After a dose $9 \mu \mathrm{g}$. $/ \mathrm{kg}$. I.A. the intraluminal pressure rose to $\mathrm{Io} \mathrm{mm}$. $\mathrm{Hg}$, from $6 \mathrm{~mm}$. $\mathrm{Hg}$.

In one dog the effect of phenylephrine $2 \mu \mathrm{g}$. $/ \mathrm{kg}$. I.A. upon the cystometrogram was determined in a full experiment. The voiding pressure was elevated, the bladder capacity was lowered and the residual urine was lessened by this alpha-adrenergic activating drug, an effect quite opposite to that elicited by isoproterenol (Table XI).

\section{CONCLUSION}

In conclusion, our experiments have shown that isoproterenol lowers the maximum voiding pressure, raises the bladder capacity and impairs the emptying of the bladder. It also lowers the intravesical pressure. This effect is opposite to that of phenylephrine and not altered by alpha-adrenergic blockade by phentolamine nor parasympathomimetic blockade by atrophine. The effect can be elicited after intravenous and intra-arterial injection, is reversible, and is not in phase with the hypotension created by the injection. It was elicited in cats as well as dogs.

We believe that the bladder has beta-adrenergic receptors and suggest that the sympathetic nerves in the bladder can function as the 'filling nerves', postulated by Ingersoll and Jones (I958). Learmonth (I93I) has reported vesical relaxation after hypogastric nerve stimulation in human patients and subjects. Organs which. contain both alpha- and beta-adrenergic receptors render nerve stimulation experiments complex to perform and difficult to interpret unless pharmacologic procedures and concepts are invoked.

\section{ACKNOWLEDGEMENT}

Acknowledgement is gratefully made to the Veterans Administration, National Institutes of Health, the Vocational Rehabilitation Administration and the Mead Johnson Company for aid and support.

\section{REFERENCES}

Bellau, B. (1967). Stereochemistry of adrenergic receptors: newer concepts in the molecular mechanism of action of catecholamines and anti-adrenergic drugs at the receptor level. Ann. N.Y. Acad. Sci. 139, 580.

Bors, E. (1963). Some Anatomical and Physiological Aspects of Urinary Bladder Function in Spinal Injuries, p. 33, Ed. Harris, Phillip. Edinburgh : The Royal College of Surgeons of Edinburgh.

Boyarsky, S. \& LABAy, P. Unpublished data.

Boyarsky, S., Labay, P., Levie, B. \& GregG, R. (1967). Presence of beta-adrenergic receptors in urinary bladder : response to esoproterenol. The Pharmacologist, Vol 9.

BRADLEY, W. E. (1967). Ontogeny of central regulation of visceral reflex activity in the rabbit. Am. F. Physiol. $212,335$.

Carpenter, F. G. (1967). Motor responses of the urinary bladder and skeletal muscle in Botulinum intoxicated rats. F. Physiol. Lond. 188, I.

CARPENTER, F. G. \& RAND, S. A. (I965). Relation of acetylcholine release to responses of the rat urinary bladder. F. Physiol. Lond. 180, 37 I.

Cheshire, G. B. \& ThORPE, R. H. (1965). The atropine-resistance of the response to intrinsic nerve stimulation of the guinea pig bladder. Br. F. Pharmac. Chemother. 25, 288.

EL-BADAWI, A. \& SCHENK, E. A. (1966). Dual innervation of the mammalian urinary bladder. A histochemical study of the distribution of cholinergic and adrenergic nerve. $A m . \mathcal{F}$. Anat. 119, 405. 
Girado, J. N. \& CAMPBell, J. B. (1959). The innervation of the urethra of female cat. Expl Neurol. I, 44.

GREENE, L. F. \& EMMETT, J. L. (1963). Physiology of the normal bladder ; neurophysiology of micturition, In Urology, Vol I, Ed. Meredith Campbell, 2nd ed. Philadelphia : Saunders.

GYERMEK, L. (I96I). Cholinergic stimulation and blockade on urinary baldder. Am. $\mathcal{F}$. Physiol. 201, 325.

Hukovic, S., RAND, M. J. \& Vanov, S. (1965). Observations on an isolated innervated preparation of rat urinary bladder. Br. F. Pharmac. Chemother. 24, I78.

INNES, I. R. \& NICKERSON, M. (1965). Drugs acting on post-ganglia adrenergic nerve endings and structures innervated by them (sympathomimetic drugs). In The Pharmacological Basis of Therapeutics, Chap. 24, Ed. Goodman, L. F. \& Gilman, A. New York: MacMillan.

Kuntz, A. (1953). Innervation of the urinary organs. In The Autonomic Nervous System, p. 269. Philadelphia : Lea and Febiger.

Kuru, Masaru (1965). Nervous control of micturition. Physiol. Rev. 45, 426.

LEARMONTH, J. (I93I). A contribution to the neurophysiology of the urinary bladder in man. Brain, 54, 147.

Perlmutter, A. (1967). Long term effects on unilateral vesical denervation in a canine bifid bladder preparation. Invest. Urol. 4, 539.

SIGG, E. B. \& SIGG, T. D. (I964). Sympathetic stimulation and blockade of the urinary bladder in the cat. Int. $\mathcal{F}$. Neuropharmac. 3, 24I.

TANagho, E. A. \& SMith, D. R. (1966). The anatomy and function of the bladder neck. $B r . \mathcal{F}$. Urol. 33, 54.

Tanagho, E. A., Miller, E., Meyers, F. \& Corbett, R. K. (i966). Observations on the dynamics of the bladder neck. Br. F. Urol. 33, 72.

URSILlO, R. C. (I96I). Electrical activity of the isolated nerve urinary bladder strip preparation of the rabbit. Am. F. Physiol. 201, 408.

Winter, D. L., Henson, C. \& CagGiano, V. (I966). Firing patterns of urinary bladder receptors. Fedn. Proc. Fedn Am. Socs exp. Biol. Physiology abstract No. 789.

ZINNER, N. \& RITTER, R. (I967). Bladder physiology. In The Neurogenic Bladder, pp. I8-3I, Ed. Boyarsky, S. Baltimore: Williams and Wilkins.

\section{THE NEUROGENIC BLADDER OF NON-TRAUMATIC ORIGIN}

By M. Damanski, M.D., F.R.C.S.

A FEW years ago, when working in a Paraplegic Centre, I was one of the contributors to two papers on the 'Neurogenic Bladder of Non-Traumatic Origin' (Damanski and Kerr, I964; Ross, Gibbon and Damanski, 1964). In the years which followed I had a new opportunity of working in several departments for long-stay and geriatric patients. It was only then that I realised that our previous presentation of the subject was somewhat one-sided, as it was dealing mainly with the patients who needed surgical operations. When invited to write this paper I decided to give a more complete picture by including those who suffer from the so-called 'geriatric bladder'.

Generally speaking, there are diseases notorious for bladder dysfunction, such as disseminated sclerosis, tabes dorsalis and spina bifida. (I must mention that the latter is not included in the scope of this lecture.) These patients constitute a numerous group among those admitted to hospitals and are comparatively well studied. On the other hand, there are interesting selective diseases, such as subacute combined degeneration of the spinal cord and motor-neurone disease which are accompanied by bladder dysfunction at one stage or another, the nature of which has not been investigated so far. 